\title{
Isolation and characterization of an exopolygalacturonase from Fusarium oxysporum f.sp. cubense race 1 and race 4
}

\author{
Zhangyong Dong ${ }^{1,2}$ and Zhenzhong Wang ${ }^{*}$
}

\begin{abstract}
Background: Fusarium wilt is an economically devastating disease that affects banana production. Although Cavendish banana cultivars are resistant to Fusarium oxysporum f.sp. cubense race 1 (FOC1) and maitain banana production after Gros Michel was destructed by race 1, a new race race 4 (FOC4) was found to infect Cavendish.

Results: An exopolygalacturonase (PGC2) was isolated and purified from the supernatant of the plant pathogen Fusarium oxysporum f.sp. cubense race 4 (FOC4). PGC2 had an apparent Mr of 63 kDa by SDS-PAGE and 51.7 kDa by mass spectrometry. The enzyme was N-glycosylated. PGC2 hydrolyzed polygalacturonic acid in an exo-manner, as demonstrated by analysis of degradation products. To obtain adequate amounts of protein for functional studies between the PGC2 proteins of two races of the pathogen, pgc2 genes encoding PGC2 from race 4 (FOC4) and race 1 (FOC1), both $1395 \mathrm{bp}$ in length and encoding 465 amino acids with a predicted amino-terminal signal sequence of 18 residues, were cloned into the expression vector pPICZaA and then expressed in Pichia pastoris strains of SMD1168. The recombinant PGC2 products, r-FOC1-PGC2 and r-FOC4-PGC2, were expressed and purified as active extracellular proteins. Optimal PGC2 activity was observed at $50^{\circ} \mathrm{C}$ and $\mathrm{pH}$. The $K_{\mathrm{m}}$ and $V_{\max }$ values of purified r-FOC1-PGC2 were $0.43 \mathrm{mg} \cdot \mathrm{mL}^{-1}$ and 94.34 units $\mathrm{mg}^{-1}$ protein ${ }^{-1} \mathrm{~min}^{-1}$, respectively. The $K_{\mathrm{m}}$ and $V_{\max }$ values of purified r-FOC4-PGC2 were $0.48 \mathrm{mg}^{\mathrm{mL}} \mathrm{L}^{-1}$ and 95.24 units $\mathrm{mg}$ protein ${ }^{-1} \mathrm{~min}^{-1}$, respectively. Both recombinant PGC2 proteins could induce tissue maceration and necrosis in banana plants.

Conclusions: Collectively, these results suggest that PGC2 is the first exOPG reported from the pathogen FOC, and we have shown that fully functional PGC2 can be produced in the P. pastoris expression system.
\end{abstract}

\section{Background}

The banana (Musa spp.) is one of the world's most popular fruits and is regarded as the fourth most important crop in developing countries [1]. It suffers from several diseases, the most famous being Fusarium wilt disease (Panama disease), which is regarded as one of the most significant threats to banana production worldwide [2]. This disease is caused by the fungus Fusarium oxysporum f. sp. cubense (FOC) and has been reported in all banana-growing regions of the world, including Australia, Asia, Africa and Central and South America [3].

FOC has been classified into four physiological races based on pathogenicity to host cultivars in the field.

\footnotetext{
* Correspondence: zzwang@scau.edu.cn

'Laboratory of Physiological Plant Pathology, South China Agricultural

University, Guangzhou 510642, People's Republic of China

Full list of author information is available at the end of the article
}

FOC1 infects the cultivar Gros Michel; FOC2, 'Bluggoe'; FOC3, Heliconia spp.; and FOC4, Cavendish cultivars and all cultivars susceptible to FOC1 and FOC2 [4]. Earlier in the last century, FOC1 infection nearly destroyed the world's banana industry, which was based on the Gros Michel cultivar. Consequently, Gros Michel was replaced by Cavendish cultivars, which were resistant to FOC1. However, FOC4, which is capable of attacking Cavendish cultivars, was reported in Taiwan and Africa in 1967. To date, FOC4 has caused serious crop losses in Asia, Australia and Africa [5]. Grimm (2008) predicted that if FOC4 hits the banana heartland in Latin America, it could be game over for banana production in the region [6].

The plant cell wall is a barrier to the penetration and spread of phytopathogenic bacteria and fungi, so many plant pathogens produce extracellular enzymes that can
C Biomed Central

(c) 2011 Dong and Wang; licensee BioMed Central Ltd. This is an Open Access article distributed under the terms of the Creative Commons Attribution License (http://creativecommons.org/licenses/by/2.0), which permits unrestricted use, distribution, and reproduction in any medium, provided the original work is properly cited. 
degrade cell wall polymers. Cell wall-degrading enzymes and their genes have been studied for their possible role in many aspects of pathogenicity, including penetration, maceration, nutrient acquisition, plant defense induction, and symptom expression [7]. Polygalacturonases (PGs) are pectic enzymes that hydrolyze polygalacturonan, and they are the key components of pectinases. PGs are further classified into endoPGs and exoPGs, although some enzymes exhibit both endo- and exoPG activities [8]. EndoPGs (EC 3.2.1.15) cleave the backbone of polygalacturonan internally, whereas exoPGs (EC 3.2.1.67) hydrolyze monomers progressively from the nonreducing end of the substrate. ExoPGs have been reported in plant-pathogenic fungi [9] and their role in disease has been studied in the fungal plant pathogens Cochliobolus carbonum [10] and Fusarium oxysporum $\mathrm{f}$. sp. lycopersici [11]. ExoPGs may have an important function in pathogen-plant interactions because they degrade oligogalacturonides released by endoPGs to elicitor-inactive monomers [12]. Moreover, exoPGs are not subject to inhibition by plant polygalacturonase-inhibiting proteins (PGIPs) [13].

In this study, we report for the first time the isolation and purification of an exoPG (PGC2) from the supernatant of the plant pathogen FOC4. We cloned the $p g c 2$ genes of FOC1 and FOC4 and then expressed them in $P$. pastoris. Both recombinant $\mathrm{PGC} 2$ proteins retained their exoPG activity. Further studies of these genes will provide valuable insights into the role of PGC2 in FOC pathogenicity in banana cultivars.

\section{Results and Discussion}

Purification of PGC2

PG activity in the FOC4 culture supernatant could be detected when the fungi were grown in the presence of citrus pectin. PGC2 was purified from FOC4 through successive steps of ultra filtration, gel filtration chromatography and cation exchange chromatography. During the purification process, the specific PG activity increased from 3.59 to 21.30 units $\mathrm{mg}$ protein ${ }^{-1} \mathrm{~min}^{-1}$ (Table 1). One faint single peak of PG activity was seen after culture was applied to a Sephacryl S-100 16/60 gel filtration column. Subjecting the pooled PG fraction to cation exchange chromatography (Sepharose FF CM Hitrap) resulted in a significant single PG peak. SDSPAGE showed one single protein band and indicated that PGC2 was purified to homogeneity (Figure 1). According to the markers, the molecular weight of PGC2 was about $63 \mathrm{kDa}$.

\section{Characterization of PGC2}

The end products of enzymatic hydrolysis of PGA by purified enzyme were analyzed. Galacturonic acid was the only degradation product detected during enzyme activity assays, demonstrating that the purified enzyme is an exoPG.

Treatment of PGC2 with $\mathrm{N}$-glycosidase F reduced the apparent $\mathrm{Mr}$ of the enzyme from $63 \mathrm{kDa}$ to $51 \mathrm{kDa}$, as determined by SDS-PAGE, indicating that PGC2 is a glycoprotein with N-linked carbohydrate (Figure 1). A number of studies have shown that many functional proteins are glycoproteins. Glycosylation has been described in exoPG2 [14] and PG3 [15] from F. oxysporum f.sp. lycopersici.

The purified PGC2 was diluted with milli-Q water and filtered through $0.22 \mu \mathrm{m}$ pore membranes, then subjected to ESI-MS. Mass spectrometry of the purified PGC2 demonstrated many signals (Figure 2) with a molecular mass of $51.7 \mathrm{kDa}$. The result of ESI-MS also showed that the purified PGC2 may be a glycoprotein, as above.

\section{Isolation of genes encoding exopolygalacturonase PGC2 from FOC1 and FOC4}

The full-length cDNA of $p g c 2$ from FOC1 and FOC4 was cloned by 3'-RACE and 5'-RACE. A full-length 1589 nucleotide DNA sequence was isolated and sequenced. Sequencing revealed the presence of an open reading frame (ORF) of 1395 nucleotides, interrupted by four introns of 45, 47, 49 and 49 nucleotides, and encoding a predicted protein of 465 amino acids with a predicted mass of $51.7 \mathrm{kDa}$ and a predicted pI of 8.28. Analysis with SignalP V2.0 detected a putative $\mathrm{N}$-terminal signal peptide sequence of 18 amino acids that would produce a mature protein when cleaved.

Table 1 Purification of PGC2 from culture of FOC4 grown on SM supplemented with $1 \%$ citrus pectin as the sole carbon source

\begin{tabular}{|c|c|c|c|c|}
\hline Step & $\begin{array}{l}\text { Total protein } \\
(\mathrm{mg})\end{array}$ & $\begin{array}{l}\text { Total activity } \\
\text { (Unit) }^{\mathrm{a}}\end{array}$ & $\begin{array}{l}\text { Yield } \\
(\%)\end{array}$ & $\begin{array}{l}\text { Specific activity } \\
\left(\text { Units } \mathrm{mg}^{-1} \text { protein } \mathrm{min}^{-1}\right)\end{array}$ \\
\hline Crude & 36.60 & 131.25 & 100 & 3.59 \\
\hline Ultrafiltration & 8.21 & 70.26 & 53.53 & 8.56 \\
\hline Sephacryl S-100 16/60 & 1.85 & 20.35 & 15.51 & 11 \\
\hline Sepharose FF CM Hitrap & 0.26 & 5.54 & 4.22 & 21.30 \\
\hline
\end{tabular}

${ }^{a}$ One unit of PG activity was defined as the amount of enzyme that liberated one $\mu$ mole of GA in one minute at $45^{\circ} \mathrm{C}$. 

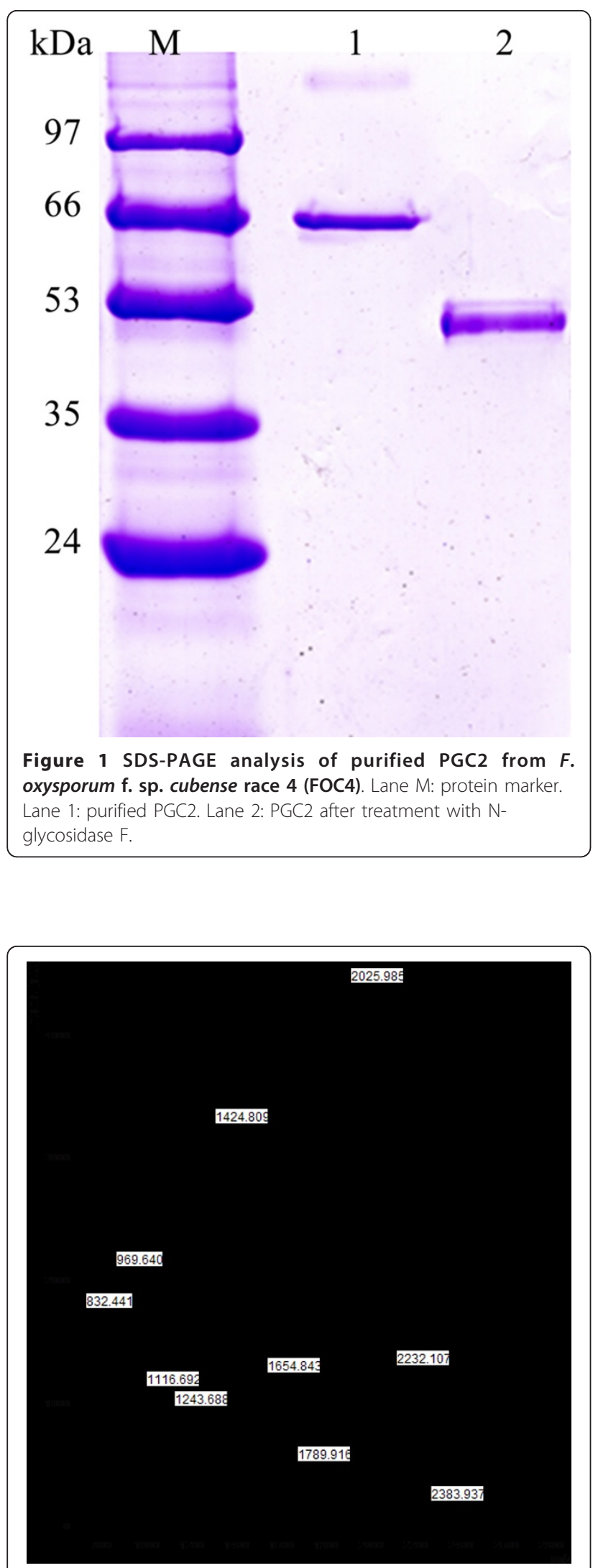

Figure 2 ESI-MS analysis of the purified PGC2 from FOC4.
The complete nucleotide sequences of $p g c 2$ genes from FOC1 and FOC4 were deposited in the GenBank database under accession numbers GU224636 and GU224637.

The nucleotide sequences of the $p g c 2$ genes from FOC1 and FOC4 and the pgx4 gene of FOL (accession number: AB256795) [16] were aligned (Figure 3). Among the three nucleotide sequences, nucleotide variation was detected at 9 positions. The sequence of $p g c 2$ from FOC4 shared as high as $99.81 \%$ and $99.43 \%$ nucleotide sequence identity with $p g c 2$ from FOC1 and the exoPG gene of FOL, respectively, while the sequence of $p g c 2$ from FOC1 shared $99.62 \%$ nucleotide sequence identity with FOL. All of the nucleotide variations were located in exons. We noted the following differences between $p g c 2$-FOC1 and $p g c 2$-FOC4: $420-\mathrm{C}$ to G, $690-\mathrm{G}$ to $\mathrm{C}$ and $886-\mathrm{G}$ to $\mathrm{C}$.

Standard protein-protein BLAST analysis revealed that both isolated PGC2 genes shared a high amino acid sequence identity with exoPGs from other fungi. Figure 4 shows the multiple alignments for the PGC2 amino acid sequences of FOC1, FOC4 and FOL (accession number: BAE97053). FOC1-PGC2 shared the same amino acid sequence with FOL and as high as 99.86\% amino acid sequence identity with FOC4PGC2. We noted the following differences between FOC1-PGC2 and FOC4-PGC2: 230-K to N, 296-D to $\mathrm{H}$. Among all prosite motifs, we found a single difference between FOC1-PGC2 and FOC4-PGC2, namely, an $\mathrm{N}$-glycosylation site (underlined in Figure 4) present in amino acids 230-233 of FOC4-PGC2 but not in FOC1-PGC2. In other words, there is no $\mathrm{N}$-glycosylation site of FOC1-PGC2 at this locus. Whether this variation has an impact on the function of PGC2 is still uncertain.

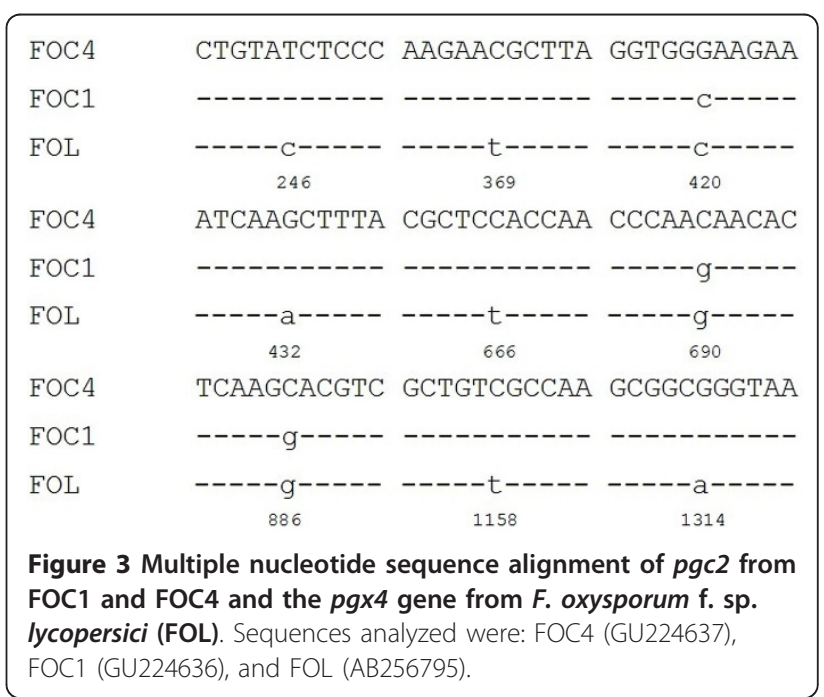




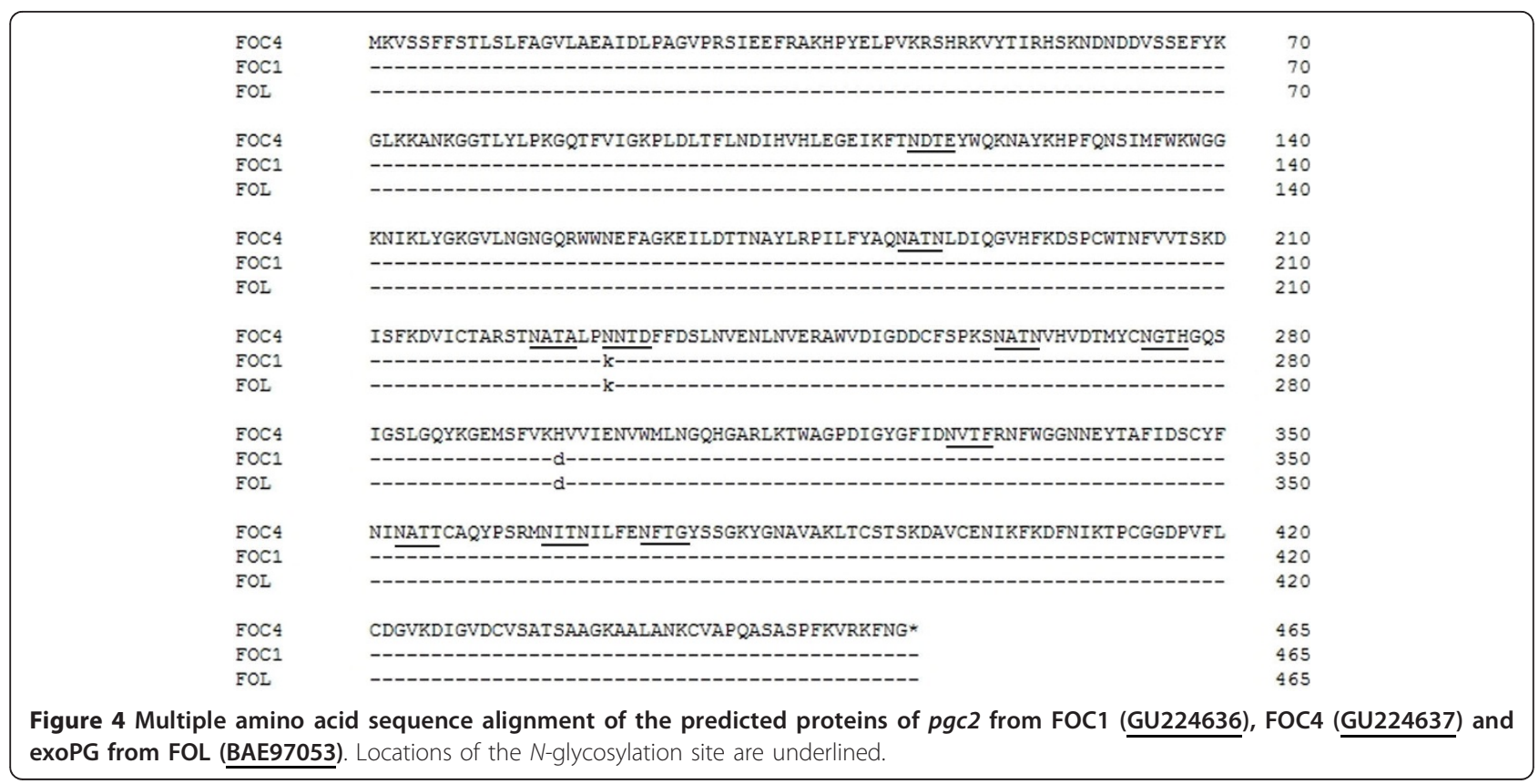

\section{Expression and purification of recombinant PGC2}

Recombinant PGC2 proteins from FOC1 and FOC4 were expressed in $P$. pastoris as secreted proteins $\mathrm{r}$ FOC1-PGC2 and r-FOC4-PGC2. Culture samples taken at 1,2 and $3 \mathrm{~d}$ post-induction were analyzed by SDSPAGE (Figure 5a). Proteins of about $63 \mathrm{kDa}$ were detected from the r-FOC1-PGC2 and r-FOC4-PGC2 transformant cultures, but were not observed in control $P$. pastoris transformed with $\mathrm{pPICZ} \alpha \mathrm{A}$ vector.

Specific PG activity was detected from the r-FOC1PGC2 and r-FOC4-PGC2 transformant cultures but not from control $P$. pastoris transformed with pPICZ $\alpha \mathrm{A}$ vector. Both recombinant PGC2s were purified through successive steps of $\left(\mathrm{NH}_{4}\right)_{2} \mathrm{SO}_{4}$ precipitation and gel filtration chromatography. During the purification process, the specific PG activity of r-FOC1-PGC2 and r-FOC4PGC2 increased from 10.5 to 58.8 units and from 12 to 77.5 units, respectively. SDS-PAGE showed one single protein band for each, indicating that r-FOC1-PGC2 and $\mathrm{r}-\mathrm{FOC} 4-\mathrm{PGC} 2$ were purified to homogeneity (Figure $5 \mathrm{~b})$. According to the markers, the molecular weight of both recombinant proteins was about $63 \mathrm{kDa}$.

\section{Biochemical characterization of recombinant PGC2}

The optimal $\mathrm{pH}$ and temperature for PG activity of the recombinant PGC2 proteins were investigated. Both enzymes exhibited the highest activity at $\mathrm{pH} 5.0$ (Figure 6a) and at $50^{\circ} \mathrm{C}$ (Figure $6 \mathrm{~b}$ ). The pH value and temperature optima for the PG activity from PG2 of FOL were reported to be 5.0 and $55^{\circ} \mathrm{C}$ [14] and the temperature optimum for the PG activity from PG3 of FOL was $55^{\circ} \mathrm{C}$ [15]. (a)

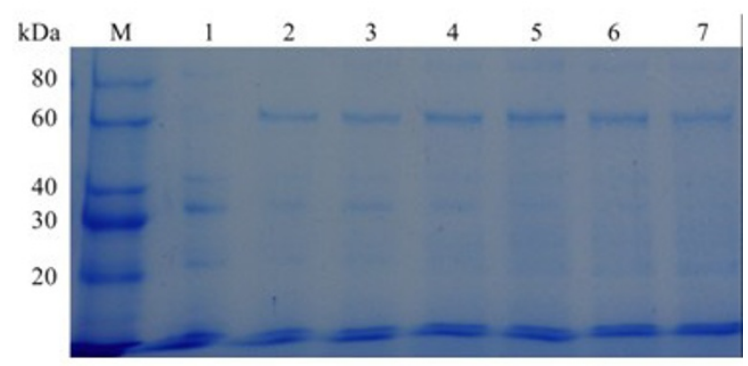

(b)

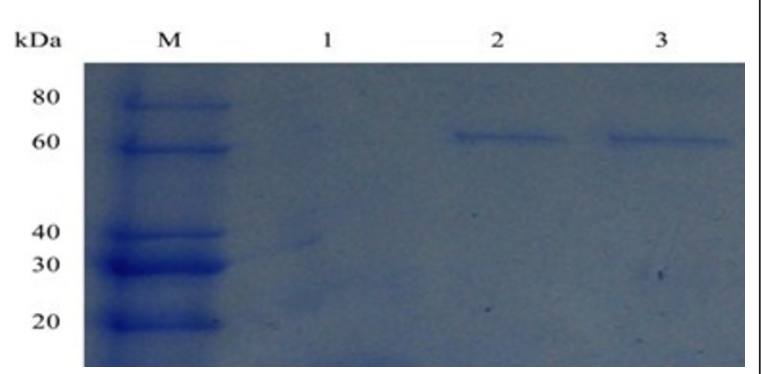

Figure 5 SDS-PAGE analysis of recombinant PGC2 from FOC1 and FOC4 produced in P. pastoris. (a) Cultures were induced for 3 $\mathrm{d}$ with methanol as described in Materials and Methods and supernatants from 1, 2, and $3 \mathrm{~d}$ were collected. Lane M: protein marker. Lane 1: cultures transformed with PPICZaA. Lane 2-4: culture supernatant from FOC1 at 1, 2, and 3 d. Lane 5-7: culture supernatant from FOC4 at 1, 2, and $3 \mathrm{~d}$. (b) SDS-PAGE analysis of purified PGC2 from FOC1 and FOC4 produced in P. pastoris. Lane M: protein marker. Lane 1: cultures transformed with pPICZaA. Lane 2: purified r-FOC1-PGC2. Lane 3: purified r-FOC4-PGC2. 


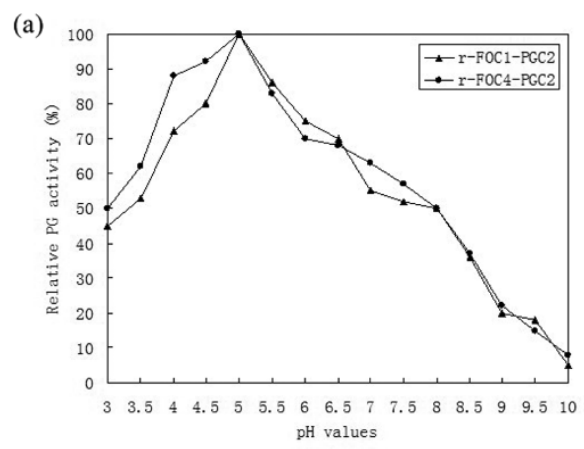

(b)

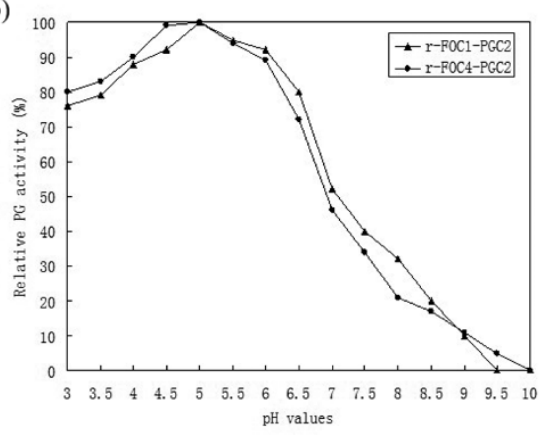

(c)

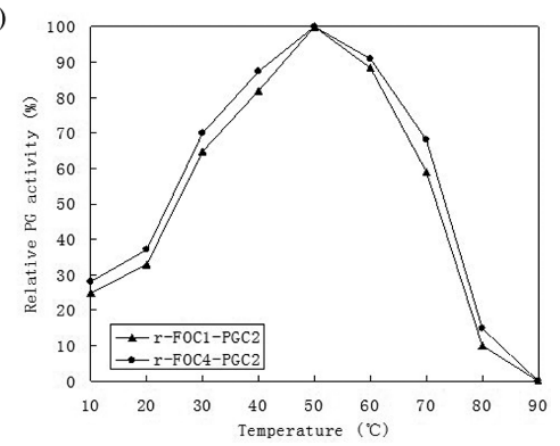

(d)

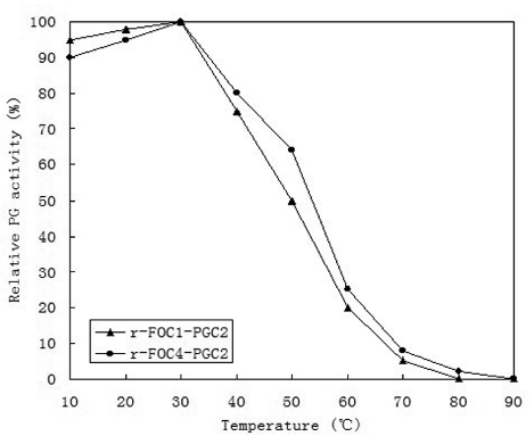

Figure 6 Enzymatic activity and stability. (a) Determination of optimal pH. (b) Enzymatic stability with respect to pH. (c) Determination of optimal temperature. (d) Enzymatic stability with respect to temperature. The enzymatic activity and stability were determined as described in the Materials and Methods. One unit of PG activity was defined as one $\mu \mathrm{mol} / \mathrm{L}$ of GA released by enzyme $\mathrm{min}^{-1}$.

To estimate the $\mathrm{pH}$ stability of recombinant PGC2, samples were incubated in buffers of different $\mathrm{pH}$ values at $4^{\circ} \mathrm{C}$ for $24 \mathrm{~h}$ and the remaining $\mathrm{PG}$ activity was assayed. Both recombinant $\mathrm{PGC} 2$ retained $>70 \%$ activity at $\mathrm{pH}$ 3-6 (Figure 6c).

To investigate the thermostability of recombinant PGC2, both enzymes were incubated at different temperatures in $100 \mathrm{mM}$ potassium phosphate buffer, $\mathrm{pH}$ 5, for $2 \mathrm{~h}$., and then residual activity was determined. Both recombinant $\mathrm{PGC} 2$ retained $>50 \%$ activity at $10-50^{\circ} \mathrm{C}$ (Figure 6d).
For hydrolysis of polygalacturonic acid (PGA) at $\mathrm{pH}$ 5.0 and $45^{\circ} \mathrm{C}$, the $K_{\mathrm{m}}$ and $V_{\max }$ of purified r-FOC1PGC2 were $0.43 \mathrm{mg} \cdot \mathrm{mL}^{-1}$ and 94.34 units $\mathrm{mg}$ protein ${ }^{-1}$ $\min ^{-1}$, respectively (Figure 7a). The $K_{\mathrm{m}}$ and $V_{\max }$ of purified r-FOC4-PGC2 were $0.48 \mathrm{mg} \cdot \mathrm{mL}^{-1}$ and 95.24 units mg protein ${ }^{-1} \mathrm{~min}^{-1}$, respectively (Figure $7 \mathrm{~b}$ ).

\section{Active recombinant PGC2 causes tissue maceration and necrosis}

Purified r-FOC1-PGC2 and r-FOC4-PGC2 proteins were inoculated onto banana tissues to examine their
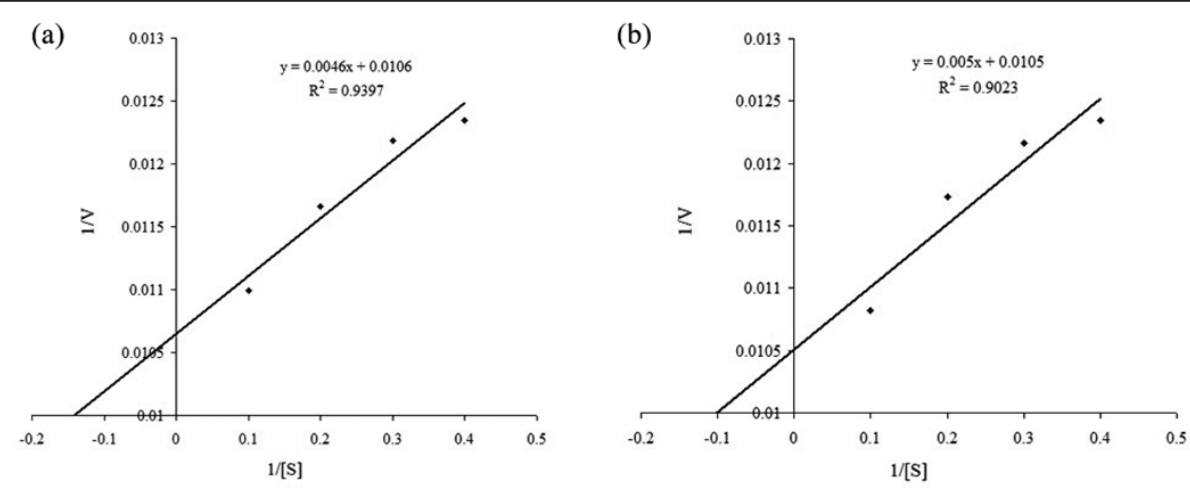

Figure 7 Lineweaver-Burk plot of purified r-FOC1-PGC2 and r-FOC4-PGC2 activity. The $K_{m}$ and $V_{\max }$ values were determined from the Lineweaver-Burk double reciprocal plots of PG activity using PGA as a substrate at concentrations between $2.5 \mathrm{mg} \mathrm{ml}^{-1}$ and $10 \mathrm{mg} \mathrm{ml}^{-1}$. (a) Purified r-FOC1-PGC2. (b) Purified r-FOC4-PGC2. 
ability to macerate tissue. Sterilized banana tissues were inoculated with 1 unit of $\mathrm{r}$-FOC1-PGC2 or $\mathrm{r}$ FOC4-PGC2 mixed with $1 \mathrm{ml}$ of $50 \mathrm{mM}$ sodium acetate buffer $\mathrm{pH}$ 5.0, and maceration was evaluated after $48 \mathrm{~h}$. The maceration activity of r-FOC1-PGC2 to Guangfen-1 (Musa AAB cv. Guangfen-1) was higher than that of r-FOC4-PGC2, while the maceration activity of r-FOC1-PGC2 to Baxi (Cavendish banana) was lower than that of r-FOC4-PGC2. Both exoPGs showed higher maceration activity on Guangfen-1 than Baxi (Figure 8). These same exoPGs showed differences in their ability to macerate two banana cultivars. These results suggest that pectins of Guangfen-1 and Baxi, as an important component of cell walls, might differ in polymer structure because Baxi pectin is a poor substrate for PGC2 compared to that of Guangfen-1.

Five days after the stems of Cavendish cultivar Baxi plants were injected with 1 unit of r-FOC1-PGC2 or r-FOC4-PGC2, the stem vascular tissues showed partial necrosis (Figure 9). The r-FOC1-PGC2 induced less necrosis compared to r-FOC4-PGC2. It seems that r-FOC1-PGC2 had a lower activity than r-FOC4PGC2. Sterile double distilled water and $50 \mathrm{mM}$ sodium acetate buffer $\mathrm{pH} 5.0$, used as controls, did not cause any symptoms when injected into stems of the bananas.

\section{Conclusions}

We demonstrated both that the $p g c 2$ genes of two races of FOC could be expressed in P. pastoris and that the recombinant proteins displayed PG activity. The two exoPGs have similar molecular structures and almost the same enzyme characteristics. Further studies of these gene products will lead to valuable insights into the role of PGC2 in FOC pathogenicity in banana cultivars.

\section{Methods}

\section{Fungal strains and growth conditions}

F. oxysporum f. sp. cubense race 4 (FOC4) was obtained from Guangzhou, China, and F. oxysporum f. sp. cubense race 1 (FOC1) was obtained from Nanning, China. The pathotype of the isolates was periodically confirmed by plant assays in a growth chamber. The cultivars tested comprised Musa AAA Cavendish cv. Baxi, resistant to FOC1 and susceptible to FOC4; Musa AAB cv. Guangfen-1, susceptible to FOC1 and FOC4.

For pectinolytic enzyme production and extraction of RNA, fungal strains were grown in SM [17] supplemented with $1 \%[\mathrm{w} / \mathrm{v}]$ citrus pectin (Sigma). For extraction of DNA, mycelium was obtained from cultures grown for $5 \mathrm{~d}$ in potato dextrose broth (PDB) in Erlenmeyer flasks on a rotary shaker at $110 \mathrm{rpm}$ and $25^{\circ} \mathrm{C}$.

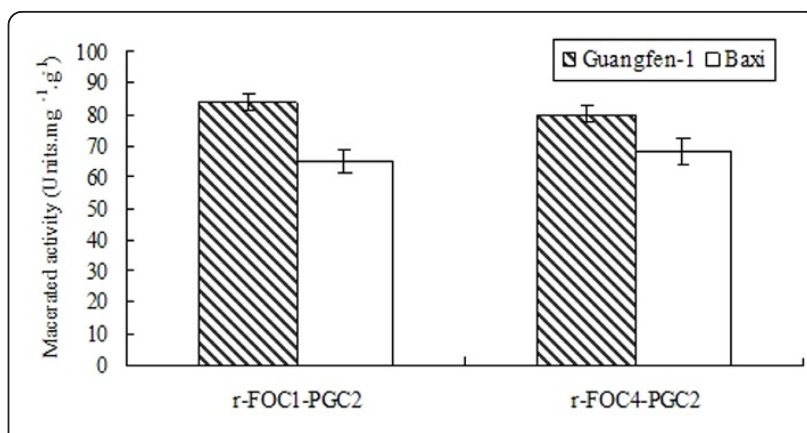

Figure 8 Enzyme maceration activity in banana tissue. 1 unit of purified enzyme mixed with $1 \mathrm{ml}$ of $50 \mathrm{mM}$ sodium acetate buffer $\mathrm{pH} 5.0$ was inoculated with sterilized banana tissues, and maceration was evaluated after $48 \mathrm{~h}$ at $45^{\circ} \mathrm{C}$. Control tubes contained the same buffer without enzyme. The reducing sugar content was determined by the method of Somogyi [18] in three replicates. (Guangfen-1: Musa AAB cv. Guangfen-1; Baxi: Musa AAA Cavendish cv. Baxi)

\section{Purification of PGC2}

Cultures of FOC4 grown in SM supplemented with 1\% citrus pectin were centrifuged at $16,000 \mathrm{~g}$ for $20 \mathrm{~min}$. Supernatant was collected and concentrated using an Amicon 8400 ultrafiltration system containing a $10 \mathrm{kDa}$ MWCO membrane.

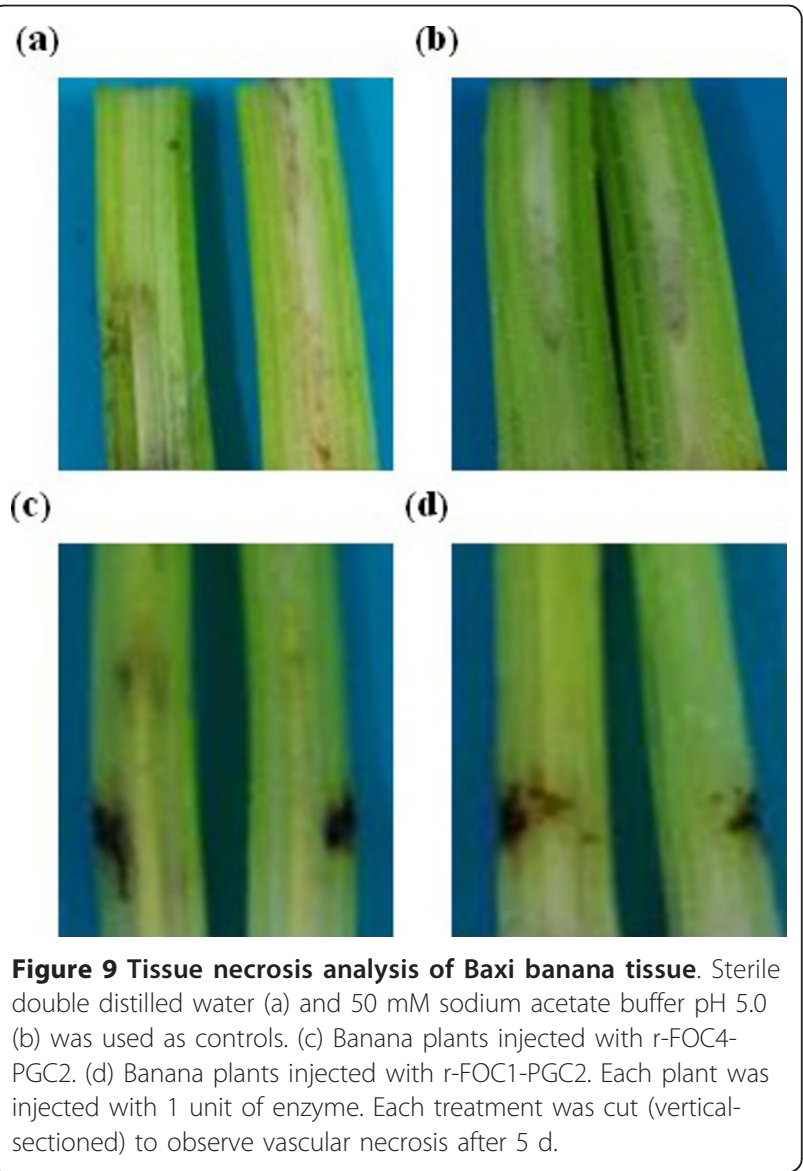


Concentrated extract filtrate was applied to a gel filtration column (Sephacryl S-100 16/60, Pharmacia) equilibrated and eluted with $50 \mathrm{mM}$ sodium acetate buffer $(\mathrm{pH} 4.5)$ at a flow rate of $1 \mathrm{ml} / \mathrm{min}$. Fractions containing PG activity were pooled and applied to a cation exchange column (Sepharose FF CM Hitrap, Pharmacia) equilibrated with $20 \mathrm{mM}$ sodium acetate buffer $(\mathrm{pH}$ 4.5). The column was eluted with a gradient of $\mathrm{NaCl}(0-$ $0.7 \mathrm{M}$ ) at a flow rate $2 \mathrm{ml} / \mathrm{min}$.

\section{PG activity and protein assays}

PG activity was routinely determined by measuring the release of reducing groups from polygalacturonate (PGA; Sigma). The standard reaction mixture $(1 \mathrm{ml}$ total volume) contained 0.5\% PGA (w/v), $50 \mathrm{mM}$ sodium acetate buffer ( $\mathrm{pH} 5.0)$, and various amounts of the enzyme preparation. After incubation at $45^{\circ} \mathrm{C}$ for $30 \mathrm{~min}$, the reducing sugar content was determined by the methods previously reported [18]. Appropriate controls without either enzyme or substrate were run simultaneously. The quantity of reducing sugar released was calculated from standards of D-galacturonic acid (GA; Sigma). One unit of enzyme activity was defined as the amount of enzyme that released $1 \mu \mathrm{mol}$ of GA equivalent per minute under the above conditions.

Discontinuous sodium dodecyl sulfate-polyacrylamide gel electrophoresis (SDS-PAGE) was performed according to Laemmli [19] using 10\% acrylamide. After electrophoresis, gels were stained with Coomassie brilliant blue G250 (Sigma). Protein concentration was determined according to the Bradford method [20] using bovine serum albumin as a standard.

\section{Biophysical characterization of the PGC2}

The purified PGC2 was resolved on SDS-PAGE, blotted onto a PVDF membrane and analyzed by electrospray ionization-mass spectrometry (ESI-MS) using a triple quadrupole instrument from Applied Biosystems, API 3000 (PE Sciex, Canada). Samples were diluted in milli$\mathrm{Q}$ water with a saturated solution of a-cyano-4-hydroxycinnamic acid containing $50 \%(\mathrm{v} / \mathrm{v})$ acetonitrile and $0.1 \%(\mathrm{v} / \mathrm{v})$ TFA. The spectra were acquired over a mass/ charge $(\mathrm{m} / \mathrm{z})$ range of 400-2000 in direct and reflective mode and were interpreted using Voyager software v.5.0.

\section{Biochemical characterization of PGC2}

For analysis of hydrolysis products, the purified enzyme (0.02 units in $0.5 \mathrm{ml}$ distilled water) was added to $1 \mathrm{ml}$ of $0.5 \%(\mathrm{w} / \mathrm{v})$ PGA in $50 \mathrm{mM}$ sodium acetate buffer $(\mathrm{pH}$ 5), incubated at $45^{\circ} \mathrm{C}$ for $10,20,30,40,50$, or $60 \mathrm{~min}$, and then assayed for PG activity. Removal of $N$-linked carbohydrate was carried out using $\mathrm{N}$-glycosidase $\mathrm{F}$ (Boehringer Mannheim, Mannheim, Germany).
Deglycosylation protocols followed the manufacturer's instructions.

The standard assay was modified to test the effects of varying $\mathrm{pH}$ and incubation temperature. To determine the optimal $\mathrm{pH}$, enzyme activity was assayed using 100 $\mathrm{mM}$ potassium phosphate buffer for $\mathrm{pH}$ values between 3 and 10 at $45^{\circ} \mathrm{C}$ and $0.5 \%(\mathrm{w} / \mathrm{v})$ PGA as substrate. The effect of temperature on PGC2 activity was determined in the same buffer at $\mathrm{pH} 5$ between $10^{\circ} \mathrm{C}$ and $90^{\circ} \mathrm{C}$. One unit of PG activity was defined as one $\mu \mathrm{mol} / \mathrm{L}$ of GA released by enzyme $\mathrm{min}^{-1}$.

To estimate $\mathrm{pH}$ stability, samples were incubated in $100 \mathrm{mM}$ potassium phosphate buffer of different $\mathrm{pH}$ values at $4^{\circ} \mathrm{C}$ for $24 \mathrm{~h}$. To evaluate the thermal stability, protein samples were incubated at different temperatures in the same buffer at $\mathrm{pH} 5$ for $2 \mathrm{~h}$. The residual activity was determined as previously described.

The $K_{\mathrm{m}}$ and $V_{\max }$ values were determined from the Lineweaver-Burk double reciprocal plot of PG activity using PGA as substrates at concentrations between 2.5 $\mathrm{mg} \mathrm{ml}^{-1}$ and $10 \mathrm{mg} \mathrm{ml}^{-1}$. The activity was assayed as previously described.

\section{Cloning of fungal $p g c 2$ genes}

For RACE PCR, total RNA from FOC4 was reversetranscribed into cDNA with murine leukemia-virus reverse transcriptase (TaKaRa). Two oligonucleotide primers were designed based on the $N$-terminal partial sequence of PGC2. The first PCR used the degenerate sense primer P1: 5'-GCNATHGAYYTNCCNGC-3', nest-PCR primer nP1: 5'-CCNGCNGGNGTNCCNMG3 , with the antisense primer Oligo(dT)20. Amplification cycles were as follows: one cycle of $3 \mathrm{~min}$ at $94^{\circ} \mathrm{C}, 35$ cycles of $94^{\circ} \mathrm{C}$ for $30 \mathrm{~s}, 48^{\circ} \mathrm{C}$ for $30 \mathrm{~s}$, and $72^{\circ} \mathrm{C}$ for $90 \mathrm{~s}$, then $10 \mathrm{~min}$ for $72^{\circ} \mathrm{C}$. The amplified fragments were gel-purified and cloned into pMD18-T (TaKaRa) and sequenced. Two primers (P2: 5'- GTAGTAGCGTTGATGTTG-3', nP2: 5'-GTAGCACGAGTCGATG-3') was designed for 5'-RACE in accordance with RT-PCR sequence, which was performed essentially as described for the 5' -Full RACE Core Set (TaKaRa).

Based on the nucleotide sequence of the RACE PCR, first-strand cDNAs were synthesized from total RNA of FOC1 and FOC4 using reverse transcriptase XL (TaKaRa) by reverse transcription polymerase chain reaction (RT-PCR) using the forward primer (5'GTGGAATTCATGAAGGTCTCGAGCTTCTTCT-3') and the reverse primer (5'- CGGTCTAGATTAACCGTTGAACTTTCTAACC-3'). The EcoRI and $\mathrm{XbaI}$ restriction sites are underlined. The following PCR conditions were used: 35 cycles with denaturation at $94^{\circ}$ $\mathrm{C}$ for $30 \mathrm{~s}$, annealing at $49^{\circ} \mathrm{C}$ for $30 \mathrm{~s}$ and extension at $72^{\circ} \mathrm{C}$ for $90 \mathrm{~s}$. An initial denaturation step of $4 \mathrm{~min}$ at $94^{\circ} \mathrm{C}$ and a final elongation step at $72^{\circ} \mathrm{C}$ for $10 \mathrm{~min}$ 
were performed. The RT-PCR products were cloned into pMD18-T (TaKaRa) and verified by nucleotide sequencing analysis, and then they were digested with $E c o$ RI and $X b a I$ and subcloned into the recombinant eukaryotic expression vector pPICZaA (Invitrogen) digested with the same enzymes to generate pPICZaA$p g c 2$-FOC1 and pPICZaA-pgc2-FOC4. The presence of the inserted $p g c 2$-FOC1 and $p g c 2$-FOC4 genes was verified by nucleotide sequencing analysis.

Genomic DNA was extracted from fungal mycelium using the E.Z.N.A Fungal DNA Kit (OMEGA) according to the manufacturer's instructions. DNA sequences were sequenced using DNA isolated from FOC1 and FOC4 as the template and primers described above.

The complete nucleotide sequences of $p g c 2$ genes from FOC1 and FOC4 were deposited in the GenBank database under accession numbers GU224636 and GU224637.

\section{Expression and purification of PGC2 in $P$. pastoris}

Yeast transformation was performed according to manufacturer's instructions. The recombinant plasmids pPIC$\mathrm{ZaA}-p g c 2-\mathrm{FOC} 1$ and pPICZaA-pgc2-FOC4 were linearized by digestion with $\mathrm{SacI}$ and transformed into $P$. pastoris SMD1168 strain by electroporation. SMD1168 strains transformed with pPICZaA plasmid and SMD1168 strains without transformation served as negative controls. Cells were incubated on yeast extract peptone dextrose (YPD) plates containing 1\% yeast extract, $2 \%$ peptone, $2 \%$ dextrose, and $100 \mu \mathrm{g} / \mathrm{ml}$ of zeocin at $28^{\circ} \mathrm{C}$ for $48 \mathrm{~h}$. Integration of the $p g c 2$ gene into the genome of $P$. pastoris was determined by PCR using 5'AOX1 and 3'AOX1 primers. The presence of the $p g c 2$ gene in transformants was confirmed by gene sequencing of PCR products.

Yeast transformants were grown in $30 \mathrm{ml}$ of BMGY medium (1\% yeast extract, $2 \%$ peptone, $1.34 \%$ yeast nitrogen base, $100 \mathrm{mM}$ potassium phosphate, $4 \times 10^{-5} \%$ biotin and $1 \%$ glycerol) at $28^{\circ} \mathrm{C}$ for $24 \mathrm{~h}$. Cell pellets were harvested and resuspended in $200 \mathrm{ml}$ BMMY (1\% yeast extract, $2 \%$ peptone, $1.34 \%$ yeast nitrogen base, $100 \mathrm{mM}$ potassium phosphate, $4 \times 10^{-5} \%$ biotin and $0.5 \%$ methanol). The cultures were returned to the incubator and grown under the same conditions, and samples were collected at 1,2 and $3 \mathrm{~d}$. $1 \mathrm{ml}$ of $100 \%$ methanol was added every $24 \mathrm{~h}$ to maintain a final concentration of $0.5 \%$, assuming that the methanol was completely utilized in $24 \mathrm{~h}$.

The cultures were centrifuged at 10,000 $\mathrm{g}$ for $20 \mathrm{~min}$ at $4{ }^{\circ} \mathrm{C}$, and supernatants were filtered through membranes $(0.22 \mu \mathrm{m}$, Millipore). The supernatant was fractionated by salting out with solid ammonium sulfate at $0-80 \%(\mathrm{w} / \mathrm{v})$ saturation. The precipitate formed was collected by centrifugation at $10,000 \mathrm{~g}$ for $20 \mathrm{~min}$ at $4^{\circ}$
$\mathrm{C}$, dissolved in $50 \mathrm{mM}$ sodium acetate buffer ( $\mathrm{pH} 5.0$ ), and then dialyzed overnight against the same buffer at $4^{\circ} \mathrm{C}$.

After centrifugation, recombinant r-FOC1-PGC2 and r-FOC4-PGC2 were further purified using a gel filtration column (Sephacryl S-100 16/60, Pharmacia) equilibrated and eluted with $50 \mathrm{mM}$ sodium acetate buffer ( $\mathrm{pH}$ 5.0) at a flow rate of $1 \mathrm{ml} / \mathrm{min}$. Fractions containing PG activity were collected.

\section{Tissue maceration and necrosis assayed with recombinant PGC2}

To evaluate tissue maceration, the cultivars tested comprised Musa AAA Cavendish cv. Baxi, resistant to FOC1 and susceptible to FOC4; Musa AAB cv. Guangfen-1, susceptible to FOC1 and FOC4. $1 \mathrm{~cm}$ lengths of tissue $(0.5 \mathrm{~g})$ were taken from the healthy stems of the four leaf stage banana and placed in test tubes. A mixture of 1 unit of purified enzyme with $1 \mathrm{ml}$ of $50 \mathrm{mM}$ sodium acetate buffer, $\mathrm{pH}$ 5.0, was inoculated with the sterilized banana tissue, and maceration was evaluated after $48 \mathrm{~h}$. Control tubes contained the same buffer without enzyme. Released reducing sugar was calculated from standards of GA after incubation $48 \mathrm{~h}$ at $45^{\circ} \mathrm{C}$. The reducing sugar content was determined by the method of Somogyi [18].

For the tissue necrosis assay, 1 unit of enzyme was applied to the stems of healthy banana plant by injection. For each treatment, stems were cut (vertical-sectioned) $5 \mathrm{~d}$ later to observe vascular necrosis, ten replicates. Sterile double distilled water and $50 \mathrm{mM}$ sodium acetate buffer $\mathrm{pH} 5.0$ were used as controls.

\section{Abbreviations}

FOC4: Fusarium oxysporum f.sp. cubense race 4; FOC1: Fusarium oxysporum f sp. cubense race 1; FOL: Fusarium oxysporum f.sp. Iycopersici; PG: polygalacturonase; ExoPG: exopolygalacturonase; PGC2: An exopolygalacturonase of Fusarium oxysporum f.sp. cubense race 4; PGA: polygalacturonic acid.

\section{Acknowledgements}

This work was supported by grants from the National Natural Science Foundation of China (NSFC, No. 30671349), united projects of NSFC and Guangdong Province Government (No. u0771001) and Special Fund for Agro-scientific Research in the Public Interest from Ministry of Agriculture (200903049-05).

\section{Author details}

'Laboratory of Physiological Plant Pathology, South China Agricultural University, Guangzhou 510642, People's Republic of China. 'Zhongkai University of Agriculture and Engineering, Guangzhou 510225, People's Republic of China.

\section{Authors' contributions}

ZW defined the concept and experiments of this study. ZD performed research and analyzed data. ZD and ZW drafted the manuscript. ZD and ZW have read and approved the final manuscript.

Received: 24 March 2011 Accepted: 15 September 2011

Published: 15 September 2011 


\section{References}

1. Heslop-Harrison JS, Schwarzacher T: Domestication, genomics and the future for banana. Ann Bot-London 2007, 100:1073-1084.

2. Cheesman E: Pathology of the Banana. Nature 1962, 194:223.

3. Ploetz RC: Fusarium wilt of banana is caused by several pathogens referred to as Fusarium oxysporum f. sp cubense. Phytopathology 2006, 96:653-656.

4. Persley GJ: Banana and Plantain Breeding Strategies. Proceedings of an International Workshop Held at Cairns. Australia. State Mutual Book \& Periodical Service, Ltd; 1987.

5. Hwang SC, Ko WH: Cavendish banana cultivars resistant to fusarium wilt acquired through somaclonal variation in Taiwan. Plant Dis 2004, 88:580-588.

6. Grimm D: PLANT GENOMICS A Bunch of Trouble. Science 2008, 322:1046-1047.

7. Walton JD: Deconstructing the cell-wall. Plant Physiol 1994, 104:1113-1118.

8. RB WR, Cooper RM: Cell wall-degrading enzymes of vascular wilt fungi. II. Properties and modes of action of polysaccharidases of Verticillium albo-atrum and Fusarium oxysporum f. sp. lycopersici. Physiol Mol Plant $P$ 1978, 13:101-134.

9. Riou C, Freyssinet G, Fevre M: Purification and Characterization of Extracellular Pectinolytic Enzymes Produced by Sclerotinia sclerotiorum. Appl Environ Microbiol 1992, 58:578-583.

10. Scott-Craig JS, Cheng YQ, Cervone F, De Lorenzo G, Pitkin JW, Walton JD: Targeted mutants of Cochliobolus carbonum lacking the two major extracellular polygalacturonases. Appl Environ Microbiol 1998, 64:1497-1503.

11. Garcia-Maceira Fl, Di Pietro A, Roncero Ml: Cloning and disruption of pgx4 encoding an in planta expressed exopolygalacturonase from Fusarium oxysporum. Mol Plant Microbe 2000, 13:359-365.

12. Favaron FAPM: Polygalacturonase isozymes and oxalic acid produced by Sclerotinia sclerotiorum in soybean hypocotyls as elicitors of glyceollin. Physiol Mol Plant P 1988, 385-395.

13. de Cervone FLGP: Can Phaseolus PGIP inhibit pectic enzymes from microbes and plants? Phytochemistry 1990, 447-449.

14. Di Pietro A, Roncero M: Purification and characterization of an exopolygalacturonase from the tomato vascular wilt pathogen Fusarium oxysporum f. sp. lycopersici. Fems Microbiol Lett 1996, 145:295-299.

15. Garcia Maceira Fl, Di Pietro A, Roncero MIG: Purification and characterization of a novel exopolygalacturonase from Fusarium oxysporum f.sp. lycopersici. Fems Microbiol Lett 1997, 154:37-43.

16. Hirano Y, Arie T: PCR-based differentiation of Fusarium oxysporum f. sp. lycopersici and radicis-lycopersici and races of F-oxysporum f. sp. lycopersici. Journal of General Plant Pathology 2006, 72:273-283.

17. DiPietro A, Roncero M: Endopolygalacturonase from Fusarium oxysporum f. sp. lycopersici: Purification, characterization, and production during infection of tomato plants. Phytopathology 1996, 86:1324-1330.

18. Smogyi M: Notes on sugar determination. J Biol Chem 1952, 195

19. Laemmli UK: Cleavage of structural proteins during the assembly of the head of bacteriophage T4. Nature 1970, 227.

20. Bradford MM: Rapid and sensitive method for quantitation of microgram quantities of protein utilizing principle of protein-dye binding. Anal Biochem 1976, 72:248-254.

doi:10.1186/1471-2091-12-51

Cite this article as: Dong and Wang: Isolation and characterization of an exopolygalacturonase from Fusarium oxysporum f.sp. cubense race 1 and race 4. BMC Biochemistry 2011 12:51.

\section{Submit your next manuscript to BioMed Central and take full advantage of:}

- Convenient online submission

- Thorough peer review

- No space constraints or color figure charges

- Immediate publication on acceptance

- Inclusion in PubMed, CAS, Scopus and Google Scholar

- Research which is freely available for redistribution

Submit your manuscript at www.biomedcentral.com/submit
Biomed Central 